\title{
INCREASED ACTIVITY OF MATURE OSTEOBLAST FROM RAT BONE MARROW- MESENCHYMAL STEM CELLS IN OSTEOGENIC MEDIUM EXPOSED TO MELATONIN
}

\author{
Yugi Hari Chandra Purnama ${ }^{1}$, Gondo Mastutik ${ }^{2}$, Suhartono Taat Putra ${ }^{2}$ \\ ${ }^{1}$ Master Program, Basic Medical Science, ${ }^{2}$ Department of Anatomic Pathology, Faculty of Medicine, Universitas \\ Airlangga, Surabaya, Indonesia
}

\section{ABSTRACT}

\begin{abstract}
Exposure to melatonin in the cultures of Bone Marrow Mesenchymal Stem Cells (BM-MSCs) in osteogenic medium is able to induce mesenchymal stem cells and preosteoblasts into active osteoblasts via several transduction signals such as ERK 1/2. Previous studies used a single dose of $50 \mathrm{nM}$ and a physiological dose of 20-200 pg/ml. The objective of the study was to obtain an optimal dose of melatonin that enhances osteoblast activity by increasing the expression of ERK1/2 and ALP levels in the culture of Rat Bone Marrow Mesenchymal Stem Cells (BM-MSCs) in osteogenic medium. This study was an in vitro experimental laboratory study using BM-MSCs from rat femoral bone grown on osteogenic medium without or with exposure to melatonin in doses of 0, 50, 100, 150 nM for 21 days. BM-MSCs were characterized by immunocytochemical techniques (CD45- and CD 105+) and ERK 1/2 expression was checked 24 hours after exposure to melatonin, while ALP levels were examined on day 21 using ELISA technique. ERK 1/2 expression on BM-MScs exposed to melatonin in doses 0, 50, 100, and $150 \mathrm{nM}$ were respectively 0.087, 0.095, 0.081, and 0.079 . Mean ERK 1/2 expression in various groups showed a decrease along with increasing doses of melatonin. Among the four treatment groups, the administration of melatonin in a dose of $50 \mathrm{nM}$ resulted in highest mean ERK 1/2 expression. ALP levels in BM-MSCs exposed to melatonin doses of 0, 50, 100, and $150 \mathrm{nM}$ were 0.128; 0.130; 0.117, and $0.111 \mathrm{ng} / \mathrm{ml}$ respectively. Data showed that decreasing mean ALP levels occurred along with the addition of melatonin dose. In conclusion, the administration of melatonin 50 $n M$ is the optimal dose to increase the differentiation of cultured rat BM-MSCs into active osteoblasts.
\end{abstract}

Keywords: Melatonin; ERK 1/2 expression; ALP level; rat BM-MSCs

\section{ABSTRAK}

Paparan melatonin pada biakan Bone Marrow Mesenchymal Stem Cells (BM-MSCs) dalam medium osteogenik mampu menginduksi sel punca mesenkimal dan preosteoblas menjadi osteoblas aktif melalui beberapa sinyal transduksi seperti ERK 1/2. Penelitian terdahulu tersebut menggunakan dosis tunggal $50 \mathrm{nM}$ dan dosis fisiologis 20-200pg/ml. Tujuan penelitian adalah mendapatkan dosis optimal melatonin yang mampu meningkatkan aktivitas osteoblas melalui peningkatan ekspresi ERK1/2 dan kadar ALP pada biakan Rat Bone Marrow Mesenchymal Stem Cells (BM-MSCs) di medium osteogenik. Penelitian ini merupakan penelitian eksperimental laboratorik in vitro menggunakan BM-MSCs dari tulang femur tikus yang dibiakkan pada medium osteogenik tanpa atau dengan paparan melatonin dosis 0, 50, 100, 150 nM selama 21 hari. BM-MSCs dikarakterisasi dengan teknik imunositokimia (CD45-dan CD 105+) dan ekspresi ERK 1/2 diperiksa 24 jam setelah paparan melatonin, sedangkan kadar ALP diperiksa hari ke21 dengan menggunakan teknik ELISA. Ekspresi ERK 1/2 pada BM-MScs yang diapapr melatonin dosis 0, 50, 100, 150 nM yaitu 0,087; 0,095; 0,081; 0,079 secara berurutan. Rerata ekspresi ERK 1/2 pada berbagai kelompok menunjukkan terjadi penurunan seiring dengan peningkatan pemberian dosis melatonin. Di antara keempat perlakuan tersebut, pemberian melatonin dengan dosis 50 nM dapat memberikan ekspresi ERK 1/2 dengan rerata tertinggi. Kadar ALP pada BM-MSCs yang dipapar melatonin dosis 0 , 50, 100, $150 \mathrm{nM}$ yaitu 0,128; 0,130; 0,117, dan 0,111 ng/ml secara berurutan. Data tersebut menunjukkan penurunan rerata kadar ALP terjadi seiring dengan penambahan dosis melatonin. Sebagai simpulan, pemberian melatonin 50 nM merupakan dosis optimal untuk meningkatkan diferensiasi biakan rat BM-MSCs menjadi osteoblas aktif.

Kata kunci: Melatonin; ekspresi ERK 1/2; kadar ALP; rat BM-MSCs

Correspondence: Gondo Mastutik, Department of Anatomic Pathology, Faculty of Medicine, Universitas Airlangga, J1. Prof Dr Moestopo 47, Surabaya 60131, phone. 62-31-5020251, ext 151. E-mail: gondomastutik@ gmail.com, gondomastutik@fk.unair.ac.id

pISSN:2355-8393 • eISSN: 2599-056x • doi: http://dx.doi.org/10.20473/fmi.v54i4.10714

- Fol Med Indones. 2018;54:282-288 • Received 9 Jan $2018 \bullet$ Accepted 20 Sep 2018

- Open access under CC-BY-NC-SA license • Available at https://e-journal.unair.ac.id/FMI/ 


\section{INTRODUCTION}

Melatonin or N-acetyl-5-methoxytryptamine is a hormone produced by the pineal gland and several other organs, such as salivary glands, gastrointestinal tract, skin, bone marrow and lymphocytes. Specifically in a dark state serotonin will be converted to N-acetylserotonin by the enzyme $\mathrm{N}$-acetyltransferase. $\mathrm{N}$ acetylserotonin will be methylated into melatonin by the hydroxyindole-O-methyltransferase enzyme. Later, melatonin will be released at night because of postsinaptic activation of the $\beta$-adrenergic receptor. Melatonin is known to improve bone health through bone remodeling mechanism as a target. The role of melatonin in bone physiology suggests that melatonin is the agent that can be selected for preventive therapy and prevent bone disease by improving therapeutic function through increased osteoblast differentiation in bone formation.

Exposure to melatonin in cultures of Bone Marrow Mesenchymal Stem Cells (BM-MSCs) in osteogenic media is capable of causing increased activity of mature osteoblasts (Radio et al 2006, Zaminy et al 2008). Research conducted by Radio et al (2006) found that single-dose melatonin administration of $50 \mathrm{nM}$ may increase BM-MSCs differentiation characterized by increased alkaline phosphatase (ALP) activity through melatonin 2 (MTR2) and Extracellular-SignalRegulated Kinases 1/2 (ERK1/2) (Radio et al 2006). Exposure to melatonin physiological doses of 20-200 $\mathrm{pg} / \mathrm{ml}$ in rat BM-MSCs in osteogenic media can lead to increased ALP activity and extracellular mineralization (Zaminy et al 2008). The study used a single dose of 50 $\mathrm{nM}$ and a physiological dose of 20-200pg/ml. However, the optimal dose of melatonin levels capable of causing increased BM-MSCs differentiation remains unknown.

Melatonin is able to induce mesenchymal stem cells and preosteoblasts into active osteoblasts via several transduction signals such as ERK 1/2 and Wnt/??catenin. Melatonin will bind to the type 2 melatonin receptor (MT2R) in mesenchymal stem cells, then directly increase MAPK (ERK 1/2) activity. The activity of MEK1/2 or ERK $1 / 2$ will activate the transduction signal, thus triggering the activation of alkaline phosphatase (ALP) in the cytoplasm (Maria \& Enderby 2014). This study aims to obtain optimal doses of melatonin which can increase osteoblast activity through increased expression of ERK1/2 and ALP levels in rat BM-MSCs cultures in osteogenic medium.

\section{MATERIALS AND METHODS}

This study was an in vitro experimental laboratory study using BM-MSCs from rat femoral bone, which cultured, expanded, passaged for 5 times, characterized, and cultured on osteogenic \pm melatonin medium for 21 days. The study was divided into four groups: group K0 (melatonin $0 \mathrm{nM}$ ), $\mathrm{K} 1$ (melatonin $50 \mathrm{nM}$ ), $\mathrm{K} 2$ (melatonin $100 \mathrm{nM}$ ), and $\mathrm{K} 3$ (melatonin $150 \mathrm{nM}$ ). BMMSCs were characterized by immunocytochemical techniques (CD45- and CD 105+) and ERK 1/2 expression was examined after 24 hours of melatonin administration. ALP levels were examined after day 21 using ELISA techniques.

\section{Isolation and culture of Bone Marrow Mesenchymal Stem Cells (BM-MSCs)}

BM-MSC was obtained from male adult Wistar strain albino rat (Rattus Norvegiccus), 6-8 weeks of age, and with healthy physical condition. Bone marrow collection was performed by aspirating femoral bone and each aspirate was transferred into a $15 \mathrm{~mL}$ sterile blue tube and diluted with sterile $1 \mathrm{xPBS}$ sufficiently to reach a total volume of $8 \mathrm{ml}$. Then, each tube was washed 2 times with the addition of $1 \mathrm{mPBS}$ of $5 \mathrm{ml}$ and its content was coupled with diluted aspirate. At each 5 $\mathrm{mL}$ aspirate the Ficoll was placed at room temperature in a $15 \mathrm{~mL}$ tube separately and the aspirate product was carefully placed on top of the Ficoll. Centrifugation was carried out at $1600 \mathrm{rpm}$ for $15 \mathrm{~min}$ at room temperature in rotating container. After centrifugation, the buffy coat at the Ficoll-PBS join was taken using a sterile Pasteur transfer pipette and the cell was inserted into a $15 \mathrm{ml}$ tube. Each sample was diluted with 1 xPBS sufficiently to achieve a total volume of $15 \mathrm{~m}$. The tubes were shaken 3-5 times to mix well. Centrifugation was performed again at $1600 \mathrm{rpm}$ for 10 minutes in a rotating container. Then, the centrifugation pellet was moved into a $5 \mathrm{~cm}$ petridish.

\section{Cell expansion and culture}

Cells obtained from the previous process were dissolved using $6 \mathrm{ml}$ ?-modified essential medium (?-MEM) and added with antibiotics (100 units/ml penicillin $\mathrm{G}$ and $100 \mu \mathrm{g} / \mathrm{ml}$ streptomycin). The result, in the form of BMMSC, was then cultured and expanded on petridish (Corning, China) $5 \mathrm{~cm}$, then expanded again to two petridish $10 \mathrm{~cm}$ (passage 5) and incubated at $37^{\circ} \mathrm{C}$ containing $5 \% \mathrm{CO} 2$, so that adjacent cells could stick together, until a $90 \%$ confluent cell condition was obtained. About 24 hours later, the results were examined under an inverted microscope to determine the profile of the cell count with an inverted microscope.

\section{BM-MSCs characterization}

Characterization of rat BM-MSCs maturation was done by analyzing the expression of CD105+ and CD45- on 
rat BM-MSCs culture using immunocytochemical staining technique. The immunocytochemical staining procedure was as follows: BM-MSCs were made into single cell with tripsination then fixed with acetone at $20^{\circ} \mathrm{C}$ for 10 minutes. Samples were blocked with $1 \%$ foetal calf serum (FCS) and treated with primary antibodies and incubated for 45 minutes to 1 hour. The sample was washed with PBS then reacted with secondary antibody and incubated 45 minutes to 1 hour at $37^{\circ} \mathrm{C}$. The sample was then reacted with FGC conjugate Fab IgG labeled (Fluorescence isothiocyanat). The sample was washed with PBS and then added with 10 ul emerc oil above the cell, then covered with a glass cover. Samples were viewed with a fluorescence microscope after 1-3 hours with a green filter (Rantam et al 2014).

\section{Melatonin exposure and osteogenic differentiation}

Cells grown in two $10 \mathrm{~cm}$ petridish to 5-times passage were then transferred to 24 well plates and given osteogenic medium. This osteogenic medium consisted of DMEM-HG, 10\% FCS, $100 \mathrm{~nm}$ dexamethasone, 0.1 $\mu \mathrm{m}$ ascorbic acid and $10 \mathrm{~nm}$ ?-glycerophosphate. After the cells were attached to the plate wall, the cells were exposed to melatonin (Ebcam, China) corresponding to the treatment groups. Each well was chosen randomly, then divided into four groups, the $\mathrm{K} 1$ (melatonin $0 \mathrm{nM}$ ), K2 (melatonin $50 \mathrm{~nm}$ ), K3 (Melatonin $100 \mathrm{~nm}$ ), and K4 (melatonin $150 \mathrm{~nm}$ ).

\section{ERK1/2 expression}

ERK activity 1/2 was assessed within 24 hours after cell culture. The ERK $1 / 2$ protein phosphorylation assessment on the experimental model could verify the activation of pathways in the cell line by preparing cell lysate and could be easily analyzed using ELISA. Identified ERK 1/2 cells using ELISA Kit were planted on 24-well plate tissue culture. Then, the cells were fixed and blocked after treatment. After that, AntiPhospho-ERK1 2 (Thr202/Tyr204) or Anti-ERK1/2 was pipetted into the wells and incubated for 1 hour at $37^{\circ} \mathrm{C}$.

Then, the wells were washed and supplemented with HRP Conjugated anti-mouse IgG and incubated at room temperature for 1 hour. The wells were again, TMB substrate solution was added to every well and incubated for 30 minutes at room temperature in darkness and later the propositional color appeared according to the amount of protein. A $50 \mu$ stop solution was added to each well which then turned from blue to yellow. Optical Density (OD) analysis was done immediately with ELISA technique at $450 \mathrm{~nm}$ wavelength (Raybiotech inc. 2004).

\section{ALP level}

Assessment of the effect of melatonin on ALP activity was performed on day 21 with RAT ALP ELISA kit (Elabscience, China). This examination was an in vitro quantitative examination using Sandwich-ELISA method by analyzing cell culture homogenates supernate obtained by separating cells from medium, then cell suspension was lysed with $200 \mu \mathrm{l}$ radio immune precipitation assay (RIPA). Then, the lysis buffer was centrifuged with $15000 x \mathrm{xg}$ oC for 15 minutes (Elabscience 2014).

The principle of ALP examination with this method was the addition of ALP specific antibodies to micro ELISA plate, then the addition of standard or sample as much as $100 \mu \mathrm{l}$, followed by the addition of biotinylated detection antibody and conjugated Avidin-Horseradish Peroxidase (HRP). ALP, biotinylated detection antibody and conjugated Avidin-Horseradish Peroxidase (HRP) showed blue color. The enzyme and substrate reaction ended with the addition of sulfuric acid solution and when the color turned yellow. Then the color was detected and the Optical Density (OD) was measured with a spectrophotometer(ELISA reader) at a wavelength of $450 \mathrm{~nm} \pm 2 \mathrm{~nm}$. The value of OD was proportional to the concentration of ALP. The concentration of ALP samples was assessed by comparing the sample OD on the standard curve (Elabscience 2014).

\section{RESULTS}

\section{BM-MSCs characterization}

Characterization of rat BM-MSCs was performed by analyzing the expression of CD45- and CD105 + on rat BM-MSCs culture. The characterization results of rat BM-MSCs showed a weak green luminescence on CD45- and strong luminescence on CD105+.

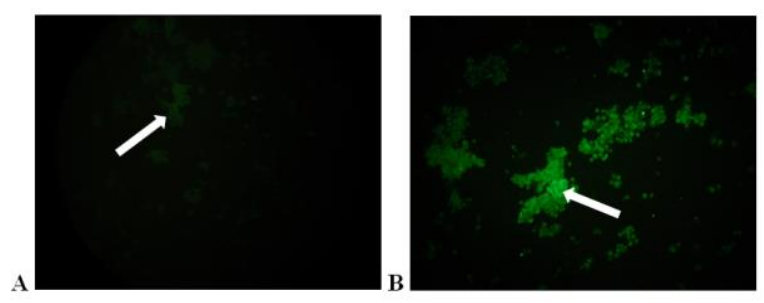

Fig. 1. Characterization of rat BM-MSCs using immunocytochemical techniques. (A) The expression of CD45-fluorescent is weak; (B) CD105 expression + fluorescent (fluorescence microscope, 200x magnification). 


\section{BM-MSCs culture}

On observation of growth in early 24 hours, the majority of observable cells were hematopoietic stem cells and few mesenchymal stem cells appeared. Five days later, mesenchymal stem cells appeared to have attached and were spindle-shaped or fibroblast-like. On the day 12 , the cells grew until it reached $90 \%$ confluence and more densely compacted.

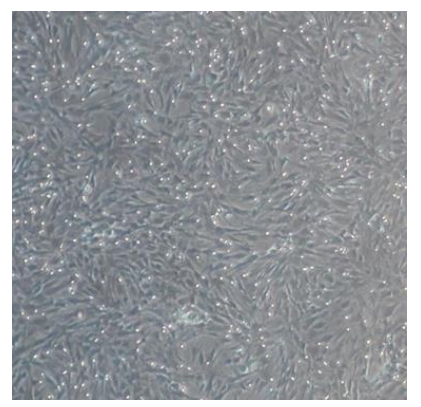

Fig. 2. BMSC that grows confluent, after validation, ready to be differentiated into more specific progenitor cells (inverted microscope, 200x magnification).

After passage 5, the cells were cultured on $1 \times 24$ medium well plates and divided into 4 groups, group 1 (control group) were BM-MSC group without melatonin [OS $+\mathrm{M}$-]; group 2 was the BM-MSC group receiving melatonin $[\mathrm{OS}+\mathrm{M}+(50 \mathrm{nM})]$, group 3 was the BMMSC group receiving melatonin [OS $+\mathrm{M}+(100 \mathrm{nM})]$, and group 4 was the BM-MSC group receiving melatonin $[\mathrm{OS}+\mathrm{M}+(150 \mathrm{nM})]$.
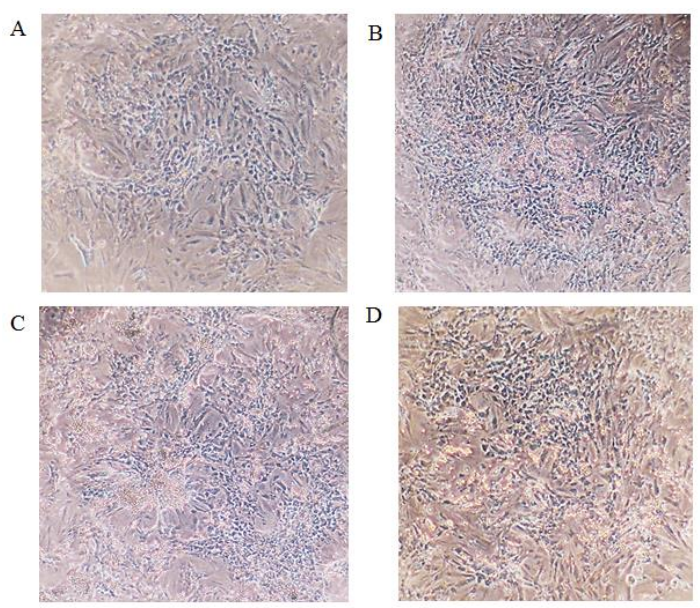

Fig. 3. The morphological features of BM-MSCs on day 21, control group (A) [OS + M-] (B) Treatment group [OS + M + (50 nM)]; (C) [OS + M + (100 $\mathrm{nM})]$; and (D) $[\mathrm{OS}+\mathrm{M}+(150 \mathrm{nM})]$; (inverted microscope, 200x magnification).

\section{ERK1/2 expression}

There were differences between the treatment groups, the control group and the group receiving melatonin doses of $50 \mathrm{nM}, 100 \mathrm{nM}$ and $150 \mathrm{nM}$. Mean ERK 1/2 expression in various groups showed a decrease in ERK $1 / 2$ expression level along with increased dose of melatonin. The ERK $1 / 2$ expression in the control group was 0.087 (SD 0.004726), 50nM 0.095 (SD 0.005508), $100 \mathrm{nM} \quad 0.081 \quad$ (SD 0.002309), $150 \mathrm{nM} \quad 0.079$ (SD 0.004359). The lowest ERK expression was in the BMMSc group of mice exposed to melatonin dose of 150 $\mathrm{nM}$ (mean 0.079), and the highest was in the BM-MSCs group exposed to melatonin dose of $50 \mathrm{nM}$ (mean 0.095).

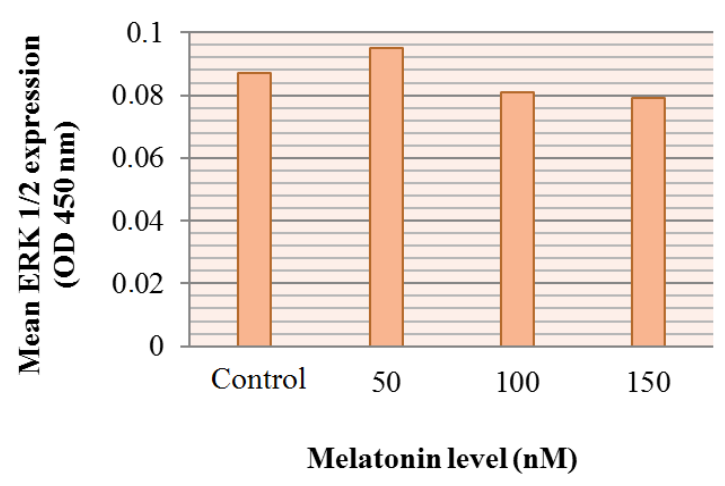

Fig. 4. Mean difference of ERK expression 1/2 between study groups.

\section{ALP levels}

There were no differences between the treatment groups, the control group and the group receiving melatonin doses of $50 \mathrm{nM}, 100 \mathrm{nM}$ and $150 \mathrm{nM}$. ALP levels in the control group with melatonin exposure of $50 \mathrm{nM}, 100 \mathrm{nM}, 150 \mathrm{nM}$ were $0.128 \mathrm{ng} / \mathrm{ml}$ (SD 2.582), $0.130 \mathrm{ng} / \mathrm{ml}$ (SD 2.651), $0.117 \mathrm{ng} / \mathrm{ml}$ (SD 2.227), and $0.111 \mathrm{ng} / \mathrm{SD}$ 2.020). The lowest ALP expression was obtained in BM-MSc group which was exposed to melatonin dose $150 \mathrm{nM}$, ie the average of $0.111(\mathrm{ng} / \mathrm{ml})$, and the highest was found in BM-MSCs group exposed to melatonin dose of $50 \mathrm{nM}$ ie $0.130(\mathrm{ng} / \mathrm{ml})$. These data suggest that a decrease in mean ALP levels occurred with the addition of melatonin doses.

\section{DISCUSSION}

ERK $1 / 2$ expression in the group exposed to melatonin $50 \mathrm{nM}$ was higher than those in other groups. However, mean ERK 1/2 expression compared with that in group not exposed to melatonin $(0 \mathrm{nM})$ did not show significant differences (ERK $1 / 2$ expression in 
melatonin exposure $0 \mathrm{nM}=0.087 ; 50 \mathrm{nM}=0.095)$. ERK $1 / 2$ expression on BM-MSCs exposed to melatonin 50 $\mathrm{nM}, 100 \mathrm{nM}$ and $150 \mathrm{nM}$ showed a decrease of 0.095 ; 0.081 ; and 0.079 respectively. Among the four treatments, the administration of melatonin at a dose of $50 \mathrm{nM}$ resulted in highest mean ERK $1 / 2$ expression. It shows that exposure to melatonin at $50 \mathrm{nM}$ is the optimal dose in increasing BM-MSCs rat differentiation.

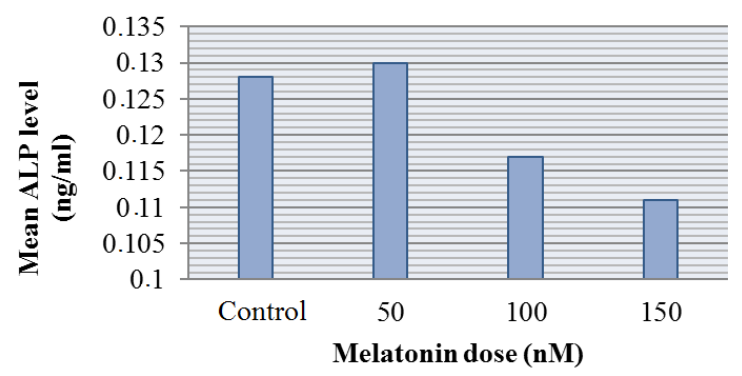

Fig. 5. Comparison of mean ALP levels between study groups.

This is in accordance with previous research results that indicate that melatonin can induce HMSCs and preosteoblasts into active osteoblasts through multiple signal transductions, including ERK 1/2 (Maria \& Enderby 2014). Luchetti et al (2014) mentions that MSCs differentiation can also be regulated by melatonin via $\mathrm{Wn} /$ ?-catenin signaling and ERK $1 / 2$ signaling. Radio et al (2006) explains that melatonin can increase the differentiation of mesenchymal stem cells through melatonin receptors 2 and ERK 1/2 signaling.

The process of ERK 1/2 phosphorylation will increase ERK $1 / 2$ level in the cytoplasm causing ERK $1 / 2$ to translocate to cell nucleus. Increased ERK $1 / 2$ in cell nucleus causes increased transcriptional activity and phosphorylation of Runx2 and Osterix (Osx). Runx2 and Osx play a role in regulating the activity of osteoblastic specific genes (Kirkham \& Cartmell, 2007; Zang, 2010). Increased activity of the osteoblastic specific gene, either through the ERK 1/2 or Wnt pathway, will trigger the differentiation of mesenchymal stem cells into activated osteoblast cells.

ALP is an enzyme secreted by osteoblasts when the osteoblasts are active. ALP is also a precipitate enzyme in matrix maturation phase. This enzyme serves to increase the concentration of inorganic phosphate and activate the collagen fiber so that it can cause the deposition of calcium salts. ALP in blood is an indicator of bone growth rate. The ALP expression is regulated by the ERK 1/2, Runx 2, Osx and WNT signals that interconnect with each other (Golub \& Bataglia, 2007).
ALP levels in the BM-MSCs group exposed to melatonin $0 \mathrm{nM}, 50 \mathrm{nM}, 100 \mathrm{nM}$, and $150 \mathrm{nM}$ showed no differences, but there was a decrease in ALP levels along with the addition of melatonin doses. Mean ALP levels of group $1(50 \mathrm{nM})$ were found to be higher than those in the other groups. However, when compared to the control group $(0 \mathrm{nM})$, the mean difference of ALP levels was not significantly different. The results of this study differed from previous research by Radio et al (2006) which states that melatonin doses of $50 \mathrm{nM}$ can increase osteogenic differentiation characterized by increased ALP activity via the melatonin 2 (MTR2) and ERK 1/2 receptor pathways using Human adult BMMSCs for 10 days. Sethi et al (2010) suggests that physiologic doses of melatonin can increase the activity of ALP, osteogenic genes (runx-2, osteocalcin and BMP2), and calcium deposition through the melatonin 2 (MTR2) and ERK 1/2 receptor pathways. Increased ALP activity and extracellular mineralization were also found in rat BM-MSCs exposed to physiological doses of melatonin in osteogenic medium (Zaminy et al 2008). The study explains that the mineralization process, which is part of the differentiation process of BM-MSCs into osteoblasts, is at day 14-28 with continuous exposure of melatonin.

The results can be influenced by several factors so that there are different results. Differences in rat BM-MSCs used are among the factors that can affect ALP levels. This can happen because every experimental animal has different stem cell properties. Another factor affecting the growth of BM-MSCs is their macro environment and micro environment. The macro environment in question is the laboratory condition, whether it is the instruments or the room used. The ability to adapt, maturity, proliferation and differentiation in micro environments also varies (Rantam et al 2014).

Differences in the time of examination may also be the cause of differences in ALP levels in the treatment group in this study from those in previous studies. In this study the ALP examination was performed on day 21, whereas, according to Birmingham et al. (2012), ALP levels occurred on days 5 to day 14 . When examined in this study, we suspect ALP levels have decreased as it has passed the phase peak (5-14 days). The ALP levels dropped gradually. Melatonin is thought to increase rat BM-MSCs differentiation, so it runs faster and the highest ALP levels have occurred on day 14 or earlier. Thus, on day 21 , rat BM-MSCs are at the end of the synthesis phase and extracellular matrix mineralization, and cellular ALP levels have decreased (Neve et al 2010). This assumption is consistent with the results of the study indicating that there is a lower level of ALP treatment groups compared to the control group. The group given melatonin will experience 
differentiation faster than control, so the ALP will be faster at the highest peak level (5-14 days) and will decrease after passing the level. The statement was supported by an alizarin red examination on day 15 which suggested that there was a calcium deposition that indicated the presence of matrix mineralization. This is the initial phase of BM-MSCs cell differentiation into preosteoblasts and subsequently turned into active osteoblasts.

Melatonin is widely known for its function as an active substance to help sleep disorders. Melatonin, also known as "hormone of darkness", has several physiological functions, such as controlling circadian rhythms, regulating body temperature, activating the immune system, controlling the secretion of growth hormone and adrenocortico hormone, enhancing osteoblast differentiation in vitro and enhancing in vivo formation as well as having a hypnotic action for sleep initiation as a driver to open a "sleep gate" (Kräuchi \& Wirz-Justice 2001).

The results showed that melatonin was able to increase BM-MSCs differentiation through increased ERK 1/2 activity pathway and ALP levels in the treatment group. There are several phases in differentiation of BM-MSCs into osteoblasts characterized by changes in MSCs to osteoprogenitors, preosteoblasts, early phases of osteoblasts, late phases of osteoblasts and mature osteoblasts. The phase of change in each phase has an important marker that indicates a change. ALP produced by osteoblasts is a marker that indicates that the preosteoblast has turned into an early phase osteoblast. The levels of ALP will continue to increase until the cells are in the final phase osteoblasts.

ALP is expressed and secreted by osteoblasts. The administration of melatonin in cultured mesenchymal stem cells may bind to its receptor, MTR2, then directly activate and phosphorylate the kinase cascade protein, ie MAPKKK (c-Raf-1), MAPKK (MEK 1/2), and MAPK (ERK 1/2) (Maria \& Enderby 2014, Park et al 2011, Zhang \& Liu 2002). The phosphorylation process of ERK $1 / 2$ will increase the level of ERK $1 / 2$ in the cytoplasm that causes ERK 1/2 to translocate to the cell nucleus. Increased ERK $1 / 2$ in the cell nucleus causes increased transcriptional activity and phosphorylation of Runx2 and Osx. Runx2 and Osx play a role in regulating the activity of osteoblastic specific genes (Kirkham \& Cartmell, 2007, Zang 2010). Increased activity of osteoblastic specific gene via ERK 1/2 pathway will trigger differentiation of mesenchymal stem cells into mature osteoblast cells that will secrete higher ALP. The results showed that the activity of ERK $1 / 2$ increased in the mesenchymal stem cell group given melatonin dose $50 \mathrm{nM}$, while those in other treatment groups were not higher than that in the control group. The increase was also obtained at ALP levels in the $50 \mathrm{nM}$ treatment group although only slightly differed from the control group, whereas in other treatment groups the increase was not higher than that in the control group. This is due to high doses of melatonin. While the ERK expression of 1/2 increased in the mesenchymal stem cell group given melatonin doses of $50 \mathrm{nM}$, that in the other treatment groups were no higher than that in the control group.

Osteoporosis is a progressive systemic skeletal disease, characterized by low bone mass and damage to the microarchitecture of bone tissue resulting in increased bone fragility and a tendency to fracture. In patients with osteoporosis, the bone will be reabsorbed rapidly by osteoclasts rather than replacement by osteoblasts so that the bones become weak and easily fracture. Although not new, melatonin can be recommended to be a therapy that can improve and regulate the process of bone formation and resorption. Pino et al (2012), reported that in osteoporotic patients, MSCs tend to differentiate into adipose, not to osteoblasts, because there is a disturbance in intrinsic properties and MSCs microenvironment. This suggests that MSCs therapy for osteoporosis patients can be a good new hope and melatonin may be considered as a growth factor supplement to obtain maximum MSCs expansion and regulate for MSCs to differentiate in osteogenic (Zaminy et al 2008, Pino et al 2012).

\section{CONCLUSION}

In the culture of rat BM-MSCs exposed to melatonin an increase in ERK expression 1/2 and no increase in ALP levels were found. The administration of melatonin 50 $\mathrm{nM}$ is the optimal dose to increase the differentiation of cultured rat BM-MSCs into active osteoblasts.

\section{REFERENCES}

Birmingham E, Niebur GL, McHugh PE, Shaw G, Barry FP, McNamara LM (2012). Osteogenic differentiation of mesenchymal stem cells is regulated by osteocyte and osteoblast cells in a simplified bone niche. European Cells And Materials 23, 13-27

Elabscience (2014). Rat ALP (Alkaline Phosphatase) ELISA Kit. 5th Edition. Elabscience Biothechnology Co, Ltd. Available from www.elabscience.com

Golub EE, Boesze-Battaglia K (2007). The role of alkaline phosphatase in mineralization. Current opinion in Orthopaedics $18,444-8$ 
Kirkham GR, Cartmell SH (2007). Genes and proteins involved in the regulation of osteogenesis. Topics in Tissue Engineering 3, 1-22

Kräuchi K, Wirz-Justice A (2001). circadian clues to sleep onset mechanisms. Neuropsychopharmacology 25, S92-6

Maria S,Witt-Enderby PA (2014). Melatonin effects on bone: potential use for the prevention and treatment for osteopenia, osteoporosis, and periodontal disease and for use in bone-grafting procedures. Journal Pineal Research 56, 115-25

Luchetti F, Canonico B, Bartolini D, Arcangeletti M, Ciffolilli, S, Murdolo, G, Piroddi, M, Papa S, Reiter RJ, Galli F (2014). Melatonin regulates mesenchymal stem cell differentiation: a Review. Journal Pineal Research 56, 382-97

Neve A, Corrado A, Cantatore FP (2011). Osteoblast Physiology in normal and pathological Condition. Cell and Tissue Research 343, 289-302

Park KH, Kang JW, Lee EM, Kim JS, Rhee YH, Kim M, Jeong SJ, Park YG, Kim SH (2011). Melatonin promotes osteoblastic differentiation through the BMP/ERK/Wnt signaling pathways. Journal Pineal Research 51, 187-94

Pino AM, Rosen CJ, Rodríguez JP, 2012. In osteoporosis, differentiation of mesenchymal stem cells (MSCs) improves bone marrow adipogenesis. Biological Research 45, 279-87
Radio NM, Doctor JS, Witt-Enderby PA (2006). Melatonin enhances alkaline phosphatase activity in differentiating human adult mesenchymal stem cells grown in osteogenic medium via MT2 melatonin receptors and the MEK/ERK1/2 signaling cascade. Journal of Pineal Research 40, 332-42

Rantam FA, Ferdiansyah, Purwati (2014). Stem Cell; meenchymal, Hematopoetik dan Model Aplikasi. 2nd Ed. Surabaya, Airlangga University Press, p 23-40

Raybiotech, inc (2004). RayBio® Cell?Based Human/Mouse/Rat ERK1/2 (Thr202/Tyr204) Phosphorylation ELISA Kit. Available from www.raybiotech.com

Sethi S, Radio NM, Kotlarczyk MP, Chen CT, Wei YH, Jockers R, Witt-Enderby PA (2010). Determination of the minimal melatonin exposure required to induce osteoblast differentiation from human mesenchymal stem cells and these effects on downstream signaling pathways. Journal of Pineal Research 49, 222-38

Zaminy A, Ragerdi Kashani I, Barbarestani M, Hedayatpour A, Mahmoudi R, Farzaneh Nejad A (2008). Osteogenic differentiation of rat mesenchymal stem cells from adipose tissue in comparison with bone marrow mesenchymal stem cells: Melatonin as a differentiation factor. Iranian Biomedical Journal 12, 133-41

Zhang W, Liu HT (2002). MAPK signal pathways in the regulation of cell proliferation in mammalian cells. Cell Research 12, 9-18 